Vol 13, Issue 6, 2020

\title{
MICROPROPAGATION OF AN ENDANGERED AND ENDEMIC MEDICINAL PLANT CAYRATIA PEDATA VAR. GLABRA
}

\author{
SHARMILA S*, RAMYA EK, MOWNIKA S, DHIVYA SM
}

Department of Botany, Vellalar College for Women (Autonomous), Erode, Tamil Nadu, India. Email: drsharmilas@yahoo.com

Received: 03 January 2020, Revised and Accepted: 20 April 2020

\section{ABSTRACT}

Objective: The objective of the present study was to develop standardization protocol for the successful in vitro mass propagation of Cayratia pedata var. glabra through leaf and stem explants, since it is a rare, endangered, and endemic medicinal plant using biotechnological involvements and to conserve this endangered species.

Methods: The application of biotechnological principles for the establishment of micropropagation under in vitro conditions has been studied by following the methods. The explants, namely, leaf and stem harvested from in vivo plants were thoroughly washed and properly sterilized with sterilients. The explants were transferred to Murashige and Skoog (MS) medium supplemented with growth regulators 6-benzyladenine (BAP) and naphthalene acetic acid (NAA) in the concentration range of $0.5-3.0 \mathrm{mg} / \mathrm{l}$ which were tested for callus induction and morphogenesis. The elongated shoots were transferred to MS medium supplemented with NAA at different concentrations for root induction.

Results: The explants collected from the field (shola) were treated in different steriliants with various concentrations at different time for sterilization. Among the various combinations tried, the Teepol treatment for 10 min followed by bavistin $20 \mathrm{~min}$, antibiotics, namely, ampicillin and rifampicin for $20 \mathrm{~min}, 70 \%$ alcohol for $30 \mathrm{~s}$, and $0.12 \% \mathrm{HgCl}_{2}$ for $3 \mathrm{~min}$ was found to be effective. The explants were cultured in MS medium supplemented with various concentrations of BAP and NAA. The results noted that an increase in the concentration of BAP concomitantly reduced the frequency of callus formation. The maximum callusing frequency and more number of shoot formation was observed in the lower concentration of BAP (0.5 mg/l) in combination with NAA $(0.2 \mathrm{mg} / \mathrm{l})$. The callus obtained from all the above combinations was sub-cultured on MS medium with same combinations of BAP and NAA. The maximum frequency of root formation in leaf callus was $85 \%$ and $75 \%$ in stem callus and both were achieved on MS medium with NAA (1 mg/l) after 2 weeks.

Conclusions: The current investigation provides a competent in vitro propagation method for C. pedata var. glabra which could be commercialized for developing identical plants with high-quality mass multiplication rate and for better conservation of the germplasm. Both the methods described here are well suited for the mass multiplication of this critically endangered and endemic climber species.

Keywords: Cayratia pedata, Murashige and Skoog, Micropropagation, Callus, Endangered.

(c) 2020 The Authors. Published by Innovare Academic Sciences Pvt Ltd. This is an open access article under the CC BY license (http://creativecommons. org/licenses/by/4. 0/) DOI: http://dx.doi.org/10.22159/ajpcr.2020.v13i6.37017

\section{INTRODUCTION}

In recent days, in vitro plant regeneration techniques or biotechnological applications have been used as an alternative technique and are remarkably benevolent in conserving rare [1,2], endangered, threatened [3,4], and endemic medicinal plants with high prudent significance [5]. According to Engelmann [6], a typical culture environment can be effectively utilized for short to medium term in vitro conservation of plant germplasm, through increasing intervals between subcultures in slow growing species. The documentation of ethnopharmacobotanical information of herbaceous plants in Thiashola (Thiashola in Tamil), Manjoor, Nilgiris South Division, Western Ghats, was undertaken with proper permission from the Principal Chief Conservator of Forests, Chennai, and the District Forest Officer, Ooty under Section 28 (i) of Wildlife Protection Act, 1972. Based on the conducted investigation, the species Cayratia pedata (Lam.) Gagnep. var. glabra Gamble was selected for the plant regeneration biotechnological research works, since this species is listed in red data book as per the IUCN red list categories, which has a wider use for different ailments among the tribes of Thiashola due to its enriched medicinal value [7-9]. C. pedata var. glabra belongs to the family Vitaceae is a weak climber, commonly known as "Kattu Pirandai" is one such endemic and endangered species in Thaisolai, Nilgiris South Division, Western Ghats, and scrambling over the hedges and trees. It is used as medicine in Siddha, Ayurveda, and Folk medicine for treating diarrhea, refrigerant, hysteria, astringent, and ulcers. A decoction is administered in uterine and other flukes.
Tissue culture technique is now oriented toward the commercial concept of large scale production of medicinally active bioactive compounds in important medicinal plants. The potentiality of the plant cell can be enhanced for the production of useful secondary metabolites by applying various in vitro techniques. It is imperative that, viable strategies have to be taken to conserve the surviving population; at least, the critically important medicinal species from further loss $[10,11]$. Since the species $C$. pedata var. glabra is rare and endangered due to ecological anthropological pressure, it is need to be conserved. As there is no strong micropropagation studies recorded on this medicinally potent climber, the present work was undertaken to lay down in vitro micropropagation as a conservation strategy to produce large scale plantlets within a short time without any genetic variation.

The findings of the current study can be useful to progress and surge further scientific investigation on the aerial parts of this species to compare the different steriliants, phytohormones, explants, and populations for micro propagation and in vitro conservation of selected species, and to determine the optimal method for the production of a greater number of plants. This protocol will serve in the future as a base to establish an in vitro genetic bank for germplasm preservation, to improve the bioactive value of these species and to isolate the genes responsible for drought resistance. 


\section{METHODS}

\section{Source of plant material}

Aerial plant of C. pedata var. glabra (Map 1 and 2) (Figs. 1 and 2) was collected from Thiashola, Manjoor, Nilgiris South Division, Western Ghats before that we got proper permission from the Principal Chief Conservator of Forests, Chennai, and the District Forest Officer, Ooty, under Section 28 (i) of Wildlife Protection Act, 1972, in the month of October and the voucher herbarium specimen was processed followed by standard methods [12]. The collected plants were identified with the help of the existing Floras [13-15] and compared with type specimens available in the herbarium of Botanical Survey of India, Southern Circle, TNAU Campus, Coimbatore (No. BSI/SRC/5/23/2010-2011/Tech. 1300), Tamil Nadu. All the preserved specimens were deposited for future reference at the Department of Botany, Vellalar College for Women (Autonomous), Erode, Tamil Nadu, India, with their accession number (VCW/BH/Acc. No.). The explants were collected from 2 to 3 years old plants from Thiashola, Manjoor, Nilgiris South Division, Western Ghats.

\section{Explants selection and mode of sterilization}

The explants, namely, leaf and stem were harvested from in vivo healthy plants, then thoroughly washed with running water and kept under running water for $20 \mathrm{~min}$. After that, the explants were washed thoroughly with Teepol solution for 5-10 min and treated with 10\% $(\mathrm{w} / \mathrm{v})$ of bavistin-methyl-3-benzimidizole carbamate solution and ampicillin and rifampicin for 15-20 min. Finally, the explants were subsequently surface sterilized with $70 \%$ alcohol for $30-60 \mathrm{~s}$ and $0.1 \%(\mathrm{w} / \mathrm{v})$ mercuric chloride solution for 3-7 min. and washed for
3-4 times in sterile distilled water. The surface sterilized explants were trimmed gently with the help of sterile surgical blade (Lister No: 10) and aseptically inoculated onto pre-cooled autoclaved medium.

Culture media employed and their composition

Murashige and Skoog (MS) [16] basal medium full strength was employed in the present study. The composition of the medium is given below:

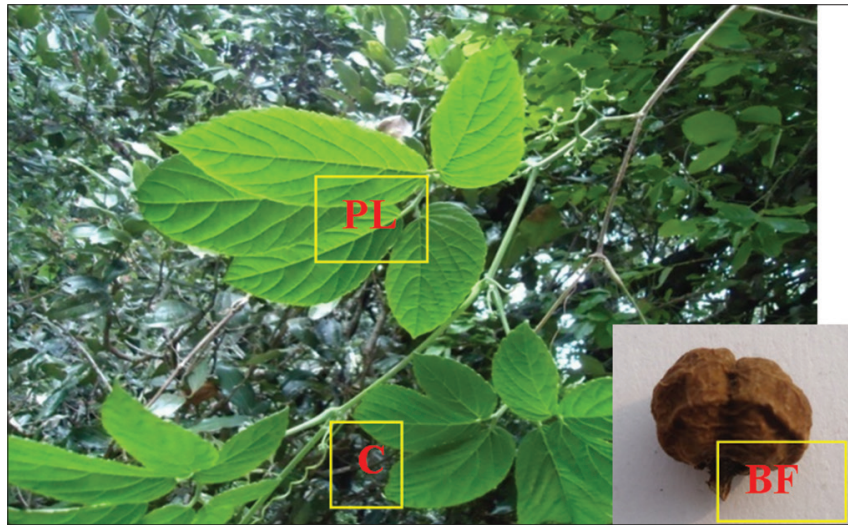

Fig. 1: The flowering twig and enlarged fruiting twig of the ecologically weaker, economically important species Cayratia pedata var. glabra. PL: Pedate leaf; C: Climber; BF: Bilobed fruit

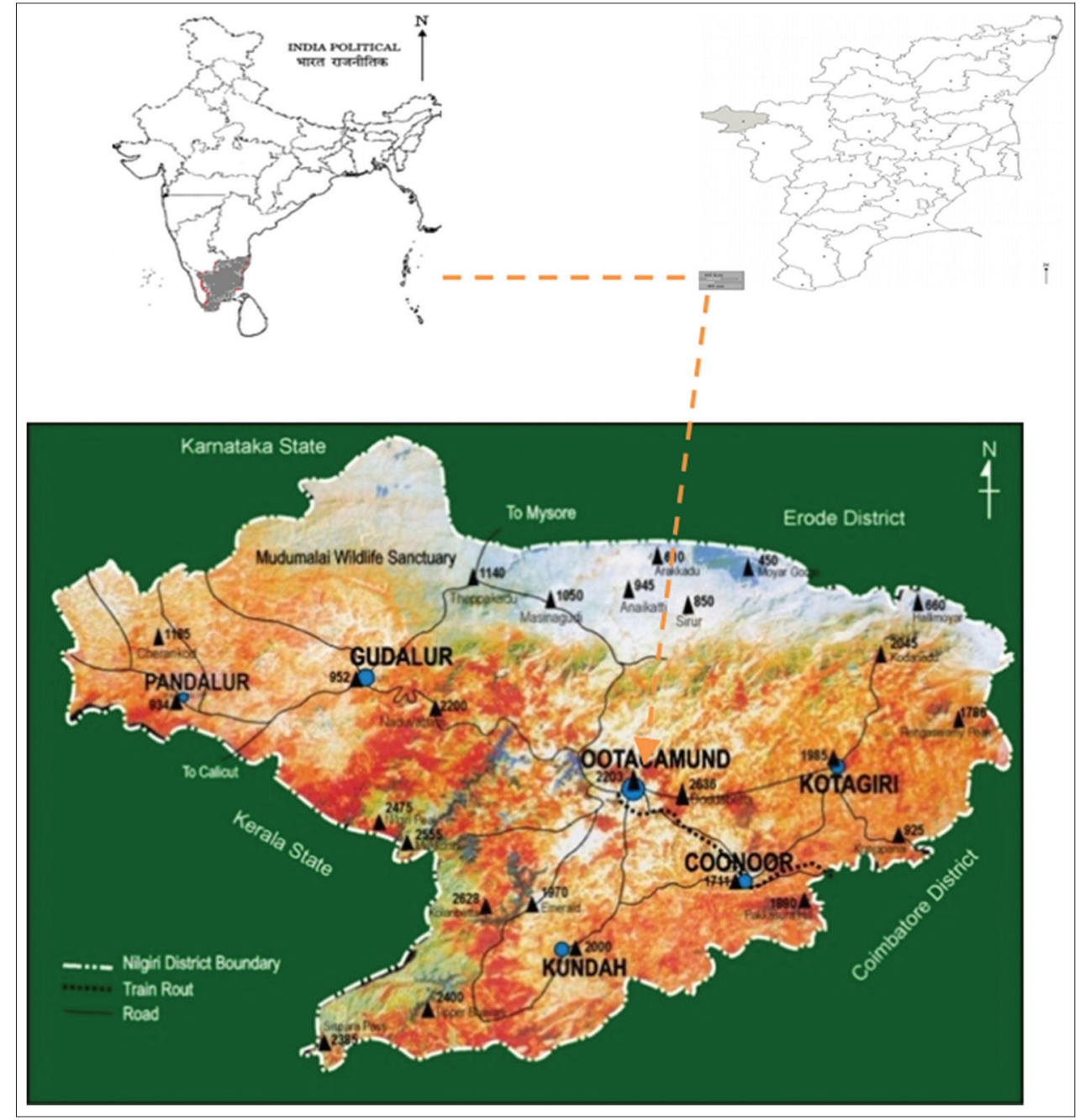

Map 1: The Nilgiri district satellite map showing important places with altitude in meter 


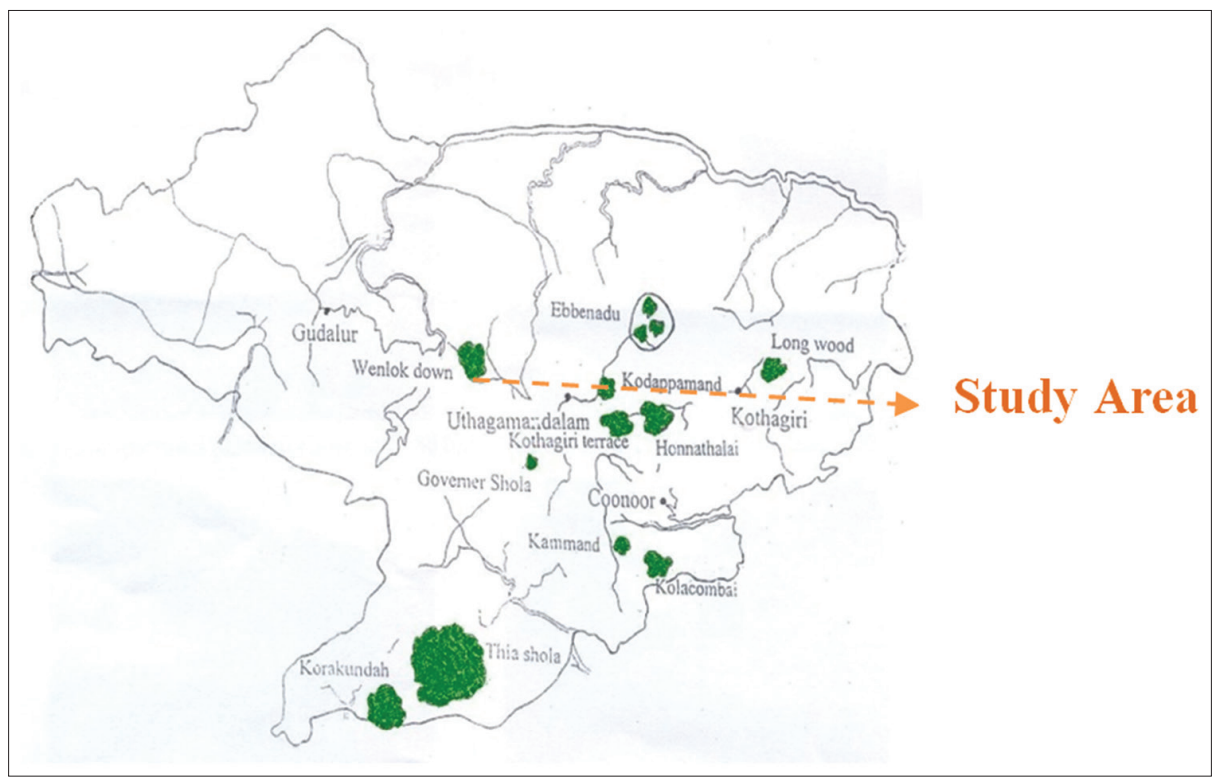

Map 2: Location of the study shola

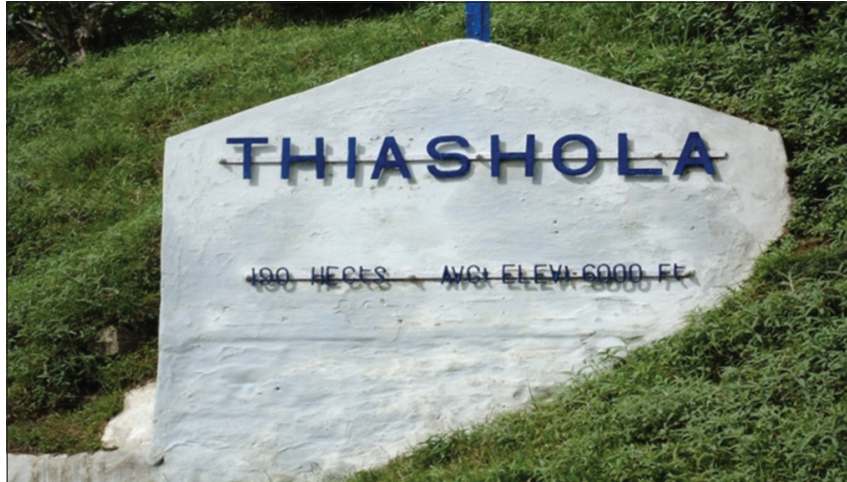

Fig. 2: Origin point of the study shola

\section{Preparation of the medium}

For the preparation of medium analytical reagents of "HiMedia" grade chemicals, "Borosil" glasswares and double distilled water were used. The nutrient medium basically consists of inorganic nutrients, carbon source, vitamins, iron source, amino acids, and natural supplements (optional). The chemicals were weighed accurately in electronic weighing balance (Shimadzu AY 220). All the stock solutions were prepared and stored in well-stoppered sterilized bottles and preserved in a refrigerator at $4^{\circ} \mathrm{C}$. Specific quantity of the stock solutions of the chemicals and growth regulators were pipetted onto a $1 \mathrm{l}$ beaker. Required sucrose and other organic supplements and complex additives (optional) were added. The final volume was made up with distilled water and the $\mathrm{pH}$ was adjusted to 5.8-5.9 with either $0.1 \mathrm{~N} \mathrm{NaOH}$ or $0.1 \mathrm{~N} \mathrm{HCl}$ using a pH meter (Systronics).

To the above said media $0.8 \%(\mathrm{w} / \mathrm{v})$ agar (extra pure gelling point $32-$ $35^{\circ} \mathrm{C}$, HiMedia, Bombay) or Phytagel (HiMedia, Bombay) was added, melted in water bath and the medium was dispensed into $150 \mathrm{ml}$ bottles (30 ml of medium). The bottles after covering with a polyethylene cap were autoclaved at $1.06 \mathrm{~kg}$ pressure $/ \mathrm{sq} \mathrm{cm}$ for about $20 \mathrm{~min}$ at $121^{\circ} \mathrm{C}$. The autoclaved medium in the culture bottles was cooled and allowed to solidify and it was stored in dark for future use. The inoculations were done after 4 days to ensure that the bottles were free from contamination.

\section{Growth regulators, growth adjuvant, and their preparation}

Two important groups of growth regulators such as auxins and cytokinins were used in the experiments. All the growth regulators are stored at $4^{\circ} \mathrm{C}$ until use.

\section{Auxins and their preparation}

Auxin, namely, $\alpha$-naphthalene acetic acid (NAA) was used in these experiments. The stock solution was prepared by dissolving $10 \mathrm{mg}$ of auxin individually in $1 \mathrm{ml}$ of ethanol. Then, the volume was made up to $100 \mathrm{ml}$ with sterile distilled water. The required volume of auxins was added to the nutrient media, before autoclaving and was used as different concentrations preparations.

\section{Cytokinins and their preparation}

The stock solution was prepared by dissolving $10 \mathrm{mg}$ of 6-benzyladenine (BAP) in $1 \mathrm{ml}$ of $0.1 \mathrm{~N}$ hydrochloric acid $(\mathrm{HCl})$ and the volume was made up to $100 \mathrm{ml}$ by adding sterile distilled water. The required volume of cytokinin was added to the nutrient media, before autoclaving and was used in different concentrations.

\section{Culture conditions}

All the cultures were maintained in the culture room at a temperature of $25 \pm S S 2{ }^{\circ} \mathrm{C}$ and relative humidity of $65-70 \%$. The cultures were kept under white light at intensity of 3000 Lux provided from white fluorescent lamps (Philips, India) with $14 \mathrm{~h}$ photoperiodic duration.

\section{In vitro studies}

The present investigations on in vitro propagation of C. pedata var. glabra were carried out in the tissue culture laboratory of the Department of Botany, Vellalar College for Women, Erode, India. In vitro techniques such as micropropagation, callus induction and regeneration were attempted.

\section{Callus induction}

The explants, namely, leaf and stem collected from Thiashola were used as primary explants. Explants measuring about $0.4-0.6 \mathrm{~cm}$ length were cultured on MS medium supplemented with growth regulators BAP and NAA. Twenty-five explants were used for each culture. Each experiment was repeated twice. MS medium enriched with BAP and NAA in the concentration range of $0.5-3.0 \mathrm{mg} / \mathrm{l}$ was tested for callus induction and morphogenesis. Sub-culturing was carried out at the regular interval of 20-30 days. The in vitro developed microshoots were cut into segments $(0.4-0.6 \mathrm{~cm}$ in length) each. These were sub-cultured on MS medium containing various growth regulators, namely, BAP and NAA in different combinations. The percentage of callus induction of 6-weekold cultures was calculated. Calli were sub-cultured regularly at an interval of 3 weeks. MS medium enriched with BAP in the concentration of $0.5-3.0 \mathrm{mg} / \mathrm{l}$ was tested for regeneration. 


\section{Callus frequency}

The percentage of callusing was recorded at the end of $5^{\text {th }}$ week. The frequency of callus induction was calculated as shown below and was represented as percentage:

$\underset{\text { Frequency of }}{\text { response }(\%)}=\frac{\text { Number of explants responded }}{\text { Total number of explants cultured }} \times 100$

\section{Rooting of in vitro multiplied shoots}

The elongated shoots were transferred to MS medium supplemented with NAA at different concentrations for root induction.

\section{Statistical analysis}

For in vitro micropropagation studies, the values are expressed as Duncan's multiple range test.

\section{RESULTS AND DISCUSSION}

Explants sterilization

The explants collected from the field (shola) were treated in different sterilants with various concentrations at different time for sterilization
(Table 1). Among the various combinations tried, the Teepol treatment for 10 min followed by Bavistin $20 \mathrm{~min}$, antibiotics, namely, ampicillin and rifampicin for $20 \mathrm{~min}, 70 \%$ alcohol for $30 \mathrm{~s}$, and $0.12 \% \mathrm{HgCl}_{2}$ for $3 \mathrm{~min}$ was found to be effective (Table 1) by having no dried explants and no contamination. The other treatment in Teepol for $10 \mathrm{~min}$ followed by Tween 20 for $10 \mathrm{~min}$, Domestos for $10 \mathrm{~min}$, Bavistin for $20 \mathrm{~min}$, antibiotics for $20 \mathrm{~min}, 70 \%$ alcohol for $30 \mathrm{~s}$, and $0.12 \%$ of $\mathrm{HgCl}_{2}$ for $3 \mathrm{~min}$ was however occupied next position to the previous treatment in terms of the degree of survivability of explants and contamination level (Table 1). However, here the response was $90 \%$ and the dried buds were around $10 \%$. Drying of explants is due to higher concentration as well as too many sterilants in the particular combinations. The explants responded along with surface contamination heavily to the $0.1 \%$ concentration, which proved that the concentration and the exposure timing were not adequate to eliminate the surface contaminants of the explants. This was in corroboration with the work of Thrope and Patel [17]. The importance of the choice of explants, which served as the inoculum for axenic culture, is well documented in the classical compilation of George and Sherrington [18].

\section{Callusing and multiple shoot induction}

Explants such as leaf and stem were employed for the induction of callus. The explants were cultured in MS medium supplemented with

Table 1: Effect of different sterilization treatments in initiation (in vivo explants of Cayratia pedata var. glabra)

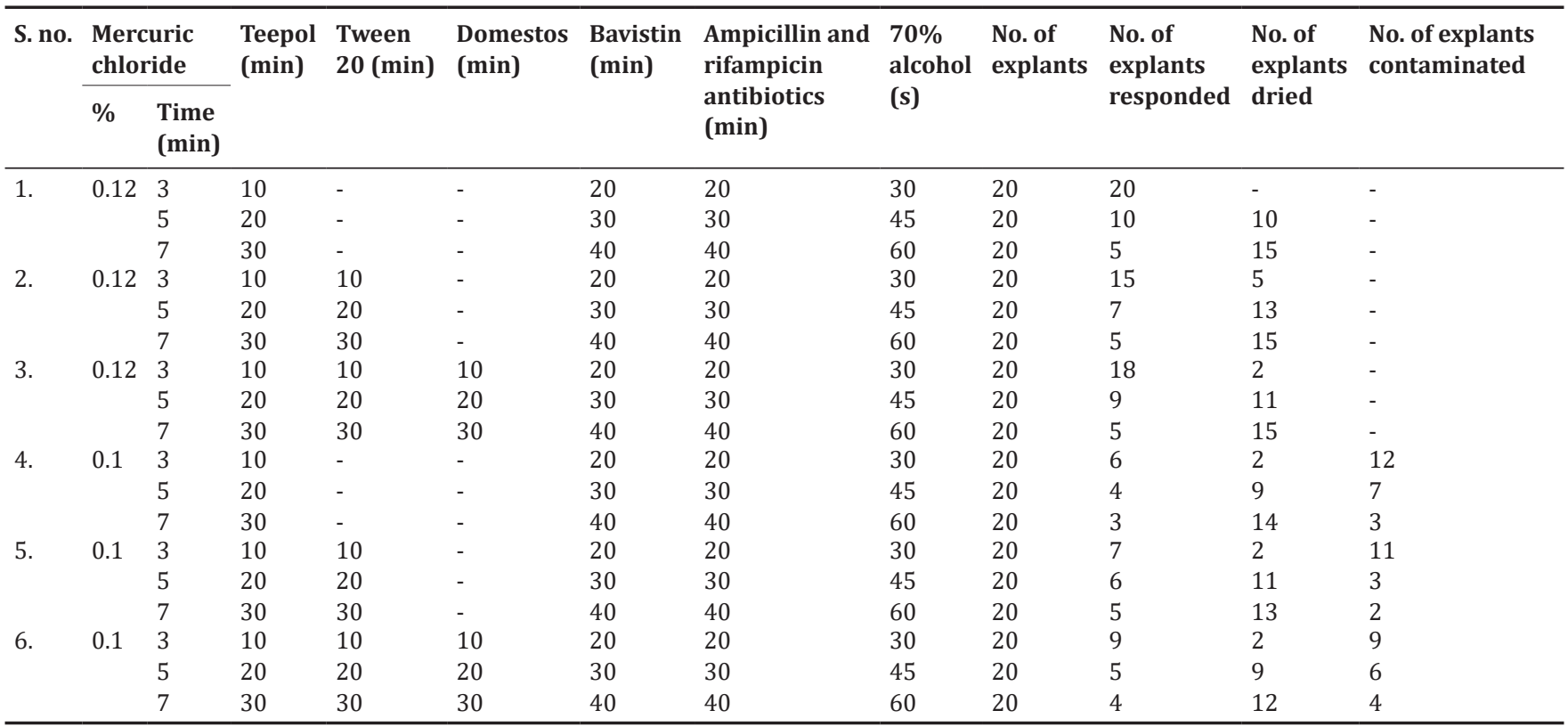

Table 2: Effect of MS medium and growth regulators on callus induction and shoot formation (in vivo explants of Cayratia pedata var. glabra)

\begin{tabular}{|c|c|c|c|c|c|c|}
\hline \multirow[t]{2}{*}{ S. no. } & \multicolumn{2}{|c|}{ MS medium+growth regulators $\mathrm{mg} / \mathrm{l}$} & \multicolumn{2}{|l|}{ Leaf } & \multicolumn{2}{|l|}{ Stem } \\
\hline & BAP & NAA & $\begin{array}{l}\% \text { of leaf } \\
\text { producing callus }{ }^{\#}\end{array}$ & $\begin{array}{l}\% \text { of callus } \\
\text { forming shoots }^{\#}\end{array}$ & $\begin{array}{l}\% \text { of stem } \\
\text { producing callus }{ }^{\#}\end{array}$ & $\begin{array}{l}\% \text { of callus } \\
\text { forming shoots }\end{array}$ \\
\hline 1. & 0.5 & 0.1 & $79.5^{d}$ & $20.0^{\mathrm{d}}$ & $80.0^{c}$ & $22.0^{\mathrm{d}}$ \\
\hline 2. & 1.0 & 0.1 & $90.0^{\mathrm{b}}$ & $15.0^{\mathrm{e}}$ & $85.0^{\mathrm{b}}$ & $15.0^{\mathrm{e}}$ \\
\hline 3. & 1.5 & 0.1 & $90.5^{b}$ & $10.0^{\mathrm{f}}$ & $87.5^{\mathrm{a}}$ & $9.0^{\mathrm{f}}$ \\
\hline 4. & 2.0 & 0.1 & $72.5^{\mathrm{e}}$ & $2.0^{\mathrm{e}}$ & $65.5^{\mathrm{e}}$ & $2.0^{\mathrm{g}}$ \\
\hline 5. & 2.5 & 0.1 & $30.5^{j}$ & - & $20.0^{\mathrm{j}}$ & - \\
\hline 6. & 3.0 & 0.1 & $25.5^{\mathrm{k}}$ & - & $18.5^{\mathrm{k}}$ & - \\
\hline 7. & 0.5 & 0.2 & $95.0^{\mathrm{a}}$ & $90.0^{\mathrm{a}}$ & $80.0^{c}$ & $75.0^{\mathrm{a}}$ \\
\hline 8. & 1.0 & 0.2 & $85.5^{c}$ & $60.0^{\mathrm{b}}$ & $70.0^{d}$ & $55.0^{\mathrm{b}}$ \\
\hline 9. & 1.5 & 0.2 & $63.5^{f}$ & $25.0^{c}$ & $60.5^{f}$ & $25.0^{c}$ \\
\hline 10. & 2.0 & 0.2 & $60.5^{g}$ & $5.0^{\mathrm{g}}$ & $58.5^{\mathrm{g}}$ & $3.0^{\mathrm{g}}$ \\
\hline 11. & 2.5 & 0.2 & $45.0^{\mathrm{h}}$ & - & $40.5^{\mathrm{h}}$ & - \\
\hline 12. & 3.0 & 0.2 & $40.0^{\mathrm{i}}$ & - & $35.0^{\mathrm{i}}$ & - \\
\hline
\end{tabular}

"Values are means of three replicates. Means followed by common superscript letter(s) are not significant at p<0.05 level. MS: Murashige and Skoog, NAA: Naphthalene acetic acid, BAP: 6-benzyladenine 
Table 3: Effect of the growth regulator on rooting of leaf and stem callus

\begin{tabular}{llll}
\hline S. no. & MS medium+Growth regulator (NAA mg/l) & \%o of rooting & \\
\cline { 3 - 4 } & & Leaf callus $^{\#}$ & Stem callus $^{\#}$ \\
\hline 1. & 1.0 & $85^{\mathrm{a}}$ & $75^{\mathrm{a}}$ \\
2. & 1.5 & $65^{\mathrm{b}}$ & $60^{\mathrm{b}}$ \\
3. & 2.0 & $50^{\mathrm{c}}$ & $50^{\mathrm{c}}$ \\
4. & 2.5 & $45^{\mathrm{d}}$ & $45^{\mathrm{d}}$ \\
5. & 3.0 & $30^{\mathrm{e}}$ & $30^{\mathrm{e}}$ \\
6. & 3.5 & $25^{\mathrm{f}}$ & $25^{\mathrm{f}}$ \\
\hline
\end{tabular}

\#Values are means of three replicates. Means followed by common superscript letter(s) are not significant at $p<0.05$ level. MS: Murashige and skoog, NAA: Naphthalene acetic acid
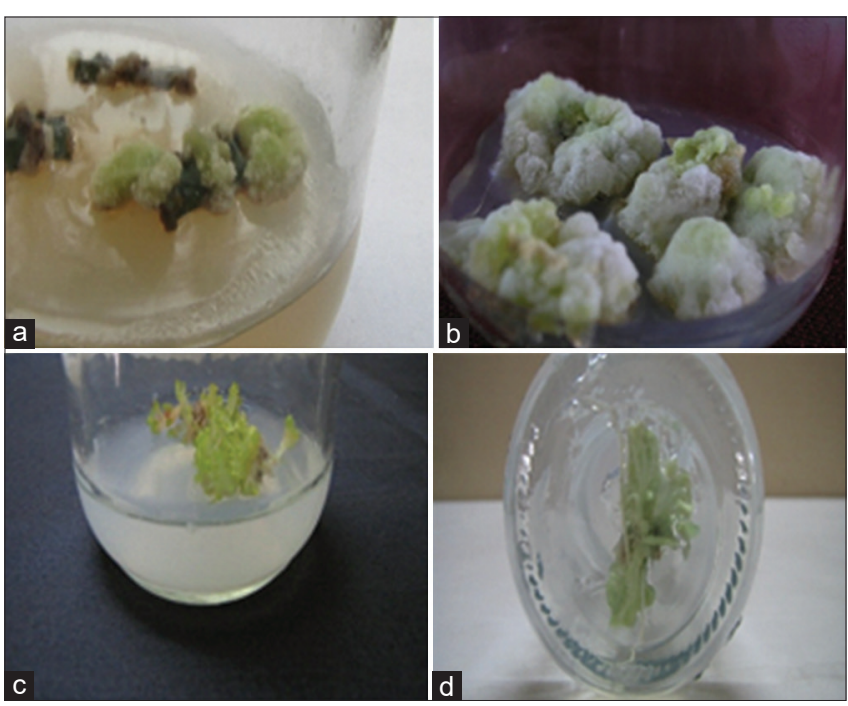

Fig. 3: In vitro culture of Cayratia. pedata var. glabra through leaf explants. a - Initiation of callus from leaf explants; $b$ - well developed callus from leaf explants; $c$ - induction of shoots from the leaf derived callus; $d$ - rhizogenesis from leaf derived callus

various concentrations of BAP and NAA (Table 2). It has been noted that an increase in the concentration of BAP concomitantly reduced the frequency of callus formation. The morphological features of callus developed from leaf and stem explants were varied widely in the present study. The callus induced from the leaves was friable, soft, and yellowish in color and grow faster than the other explant (Fig. 3). Paulsamy [19] reported the callus formation in leaf disks for a shola species Berberis tinctoria. In Berberis trifoliate, $0.5 \mathrm{mg} / \mathrm{l} \mathrm{BAP}$ and NAA actively initiate the callus formation [20].

The maximum callusing frequency and more number of shoot formation were observed in the lower concentration of BAP $(0.5 \mathrm{mg} / \mathrm{l})$ in combination with NAA $(0.2 \mathrm{mg} / \mathrm{l})$. The callus obtained from all the above combinations were sub-cultured on MS medium with same combinations of BAP and NAA. Chalupa [21] stated out that the cytokinin, benzylaminopurine (BAP) is the hormone induced the morphogenesis effectively in dicots. However, Ranganatha et al. [22] explained direct regeneration of shoots obtained in $3.0 \mathrm{mg} / \mathrm{l} 2 \mathrm{iP}$ alone and in combination with $0.1 \mathrm{mg} / \mathrm{l}$ IAA and/or $1.0 \mathrm{mg} / \mathrm{l} \mathrm{BAP}$ with average shoot length being $6.5 \pm 0.17-8.0 \pm 0.92 \mathrm{~cm}$ and percentage response was between $68 \%$ and $75 \%$. The regenerated axillary shoots were excised and transferred to MS medium with different concentrations of NAA (Table 3). The maximum frequency of root formation in leaf callus was $85 \%$ and $75 \%$ in stem callus and both were achieved on MS medium with NAA (1 mg/l) after 2 weeks.

\section{CONCLUSIONS}

The success of micropropagation and in vitro conservation of C. pedata var. glabra plant depends on the optimal selection of the explants and on the efficiency of the sterilization method. The present study concluded that the effective in vitro regeneration of the study plant on the basal medium is standardized with the hormone concentration $0.5 \mathrm{mg} / \mathrm{l}$ of BAP and $0.2 \mathrm{mg} / \mathrm{l} \mathrm{NAA}$ for shoot formation and $0.5 \mathrm{mg} / \mathrm{l}$ NAA for root initiation. The massive production of plantlets through this method will be helpful to meet the demand of this bioresource at one side. The most important step for the establishment of an in vitro culture protocol for these species is the initiation of aseptic proliferative cultures and to choose the optimal nutrient media. After this step, the multiplied material could be maintained in vitro, cryopreserved or used in restoration programs. This high regeneration system would provide an effective strategy for the conservation and proliferation of these medicinal plant species on large scale for commercial purpose.

\section{AUTHORS' CONTRIBUTION}

S. Sharmila, working as an Assistant Professor in the Department of Botany, Vellalar College for Women (Autonomous), Tamil Nadu, designed and performed the experiments. E.K. Ramya, Ph.D. Research Scholar in Botany carried out the statistical analysis and review process. S. Mownika, Ph.D. Research Scholar in Botany performed to separate the tables, figures in category. All authors read and approved the final manuscript.

\section{CONFLICTS OF INTEREST}

The authors declare that they have no conflicts of interest concerning this article.

\section{FINANCIAL SUPPORT AND SPONSORSHIP}

The work is not funded by any government funding agencies.

\section{REFERENCES}

1. Bramwell D. The role of in vitro cultivation in the conservation of endangered species. In: Conservation Techniques in Botanic Gardens. Koenigstein: Koeltz Scientific Books; 1990. p. 3-15.

2. Holobiuc M, Blindu R, Mitoi M, Heleciuc F, Cristea V. The establishment of an in vitro gene bank in Dianthus spiculifolius Schur and $D$. glacialis ssp. Ann Res 2009:52:117-28.

3. Pence VC. In vitro collecting (IVC). The effect of media and collection method on contamination in temperature and tropical collections. In vitro Cell Dev Biol Plant 2005;41:324-32.

4. Rajasekharan PE, Ambika SR, Ganeshan S. In vitro conservation of Tylophora indica: A threatened medicinal plant. IUP J Genet Evol 2009;11:26-35.

5. Sarasan V, Cripps R, Ramsay MM, Atherton C, McMichen M, Prendergast $\mathrm{G}$, et al. Conservation in vitro of threatened plants-progress in the past decade. In vitro Cell Dev Biol Plant 2006;42:206-14.

6. Engelmann F. In Vitro Conservation of Horticultural Genetic Resources. Review of the State of the Art. Rome: World Conference on Horticult Research; 1998. p. 17-20.

7. Paulsamy S. Progress Report for Annual Review Meeting Under Biosphere Reserve Meeting. New Delhi: Thiruvananthapuram, Ministry of Environment and Forest, Government of India; 2005.

8. Narayan DP, Purohit SS, Sharma K, Kumar T. A Handbook of Medicinal Plants: A Complete Source Book. Jodhpur, Rajasthan: Agro-Bios; 2007. p. 791.

9. Sharmila S, Kalaichelvi K, Abirami P. Ethnopharmacobotanical 
informations of some herbaceous medicinal plants used by Toda tribes of Thiashola, Manjoor, Nilgiris, Western Ghats, Tamil Nadu, India. Int J Pharm Sci Res 2015;6:315-20.

10. Amer A, Omar H. In-vitro propagation of the multipurpose Egyptian medicinal plant Pimpinella anisum. Egypt Pharm J 2019;18:254-62.

11. Kalaichelvi K, Sharmila S, Dhivya SM. In vitro antioxidant and antiulcerogenic activity of Cayratia pedata var. Glabra against experimentally induced gastric lesions in Wistar strain albino rats. Asian J Pharm Clin Res 2018;11:105-10.

12. Jain SK, Rao RR. Hand Book of Field and Herbarium Methods. New Delhi: Rao, R R and S K Jain;1970.

13. Fyson PF. The Flora of the Nilgiri and Pulney Hill Tops. Vol. 3. Madras: Superinendent, Government Press; 1915.

14. Gamble JS, Fischer CE. Flora of the Presidency of Madras. Vol. 1-3. Calcutta: Pragun Publications; 1967.

15. Matthew KM. The Flora of the Tamil Nadu Carnatic. Vol. 3. Tiruchirapalli: The Rapinet Herbarium, St. Joseph's College; 1983. p. $278-9$
16. Murashige T, Skoog F. A revised medium for rapid growth and bioassays with tobacco tissue cultures. Physiol Plant 1962;15:473-97.

17. Thrope TA, Patel KR. Clonal propagation: Adventitious buds. In: Cell Culture and Somatic Cell Genetics of Plants. Vol. 1. New York: Academic press; 1984. p. 49-60.

18. George EF, Sherrington PD. Plant Propagation by Tissue Culture. Florida: Exegetic, Ltd., Eversley; 1984.

19. Paulsamy S, Padmavathy S, Vijayakumar KK. Conservation of an endemic medicinal plant, Berberis tinctoria Lesch. In Nilgiris through micropropagation. Anc Sci Life 2004;1:22-6.

20. Molinar JF, Mackay WA, Wall MM, Cardenas M. Micropropogation of Agarita (Berberis trifoliate Moric.). Horticu Sci 1996;31:1030-2.

21. Chalupa V. In vitro propagation of willows (Salix sp.), European mountain ash (Sorbus aucuparia L.) and black locust (Robinia pseudoacacia L.). Biol Plant 1983;25:305-7.

22. Manjula R, Annapurna AS, Ashwani S, Nagashree R. In vitro shoot regeneration of swallow root (Decalepis hamiltonii)-a steno-endemic red listed medicinal plant. Asian J Pharm Clin Res 2020;13:189-91. 